\title{
A sour cherry orchard. An excursion through Chekhovian green spaces
}

\author{
Вѝшневый сад или Вишнёвый сад? \\ Экскурсия по зеленым просторам произведений Чехова
}

\begin{abstract}
The cherry orchard marks the end of Anton Chekhov's life, consecrating him as the author who defined the threshold of the new epoch. In this article, I construe the garden as the motif linking Chekhov's sensitivity to the general spirit of his era, revealing his poetics to the global stage as the distinctive mark of a historical and socioeconomic shift. On this path, I will clarify how the subtle difference between sour cherries and sweet cherries becomes a symbol of Chekhov's dramatic construction, and how his poetics are built on nuances and subtle shifts in meanings, representing the irrevocable fading of a culture. A philological reflection combined with an attentive reading of Chekhov's letters, Stanislavsky's memoirs and scenic sketches reveal the author's interest in the relationship between man and nature as well as the need to read his work from a more spatial-oriented standpoint. Chekhov clearly anticipates the so-called 'spatial turn', approaching space not through the description of a specific landscape or dramaturgical setting, but from a phenomenological point of view, leading him to profound reflections on the relationship between physical planning and socio-political development, as later conceptualised by key social thinkers such as Henry Lefebvre and Edward Soja. Chekhov's dramaturgical construction and symbology are the result of this awareness and endless passion for nature in all its forms.
\end{abstract}

Keywords: Anton Chekhov, theatre, cherry orchard, garden, nature, landscape

Francesca Negro, University of Lisbon, Lisbon - Portugal, francescanegro42@gmail.com, ORCID ID: https://orcid.org/0000-0001-6102-3730

While proposing a reading of The cherry orchard (Vishnevyy sad, 1903) ${ }^{1}$ through the perspective of Anton Chekhov's interest for natural spaces, I also intend to broach the symbolic and metaphorical suggestions contained in his works, revealing the epochal shift that the author operated - from a time-oriented

${ }^{1}$ All of Chekhov's works quoted here have been consulted in Russian using the edition: Anton Pavlovič Čechov, Sobranie sočinenij v dvenadcati tomah. Moskva, Gosudarstvennoe izdatel'stvo hudožestvennoj literatury, 1944-1951. 
to a space-oriented literary construction. Borrowing from Michel Foucault, we could say that Chekhov describes the passage from "an age of time to an age of space" (Foucault 1), his literary conception largely anticipating the phenomenological conception of space that will be theorised only much later, after his time. A phenomenological approach obliges us to rethink the concept of space, leaving aside any distinction between interior and exterior, approaching it as both objective reality and subjective construction deriving from the synthesis of complex experiences and multilevel interpretations (Spiegelberg XXVII, 11; Moran 4). This inspired me to perform a transversal reading of Chekhov's production, analysing his understanding of natural spaces through their value in the new socioeconomic context. At the same time, the combination of a philological reflection alongside an attentive reading of Chekhov's letters and Stanislavsky's memoirs confirmed that Chekhov's artistic interest for the relationship between man and nature reflects the synthesis of a moral and a socio-political position, awakened by the historical moment.

As posited by Barney Warf and Santa Arias, space is not simply a passive reflection of social and cultural trends but an "active participant of cultural determination" (Warf, Arias 8); this is also perfectly resumed by Barbara Hui², whose research shows how geography is constitutive as well as representative. All in all, Chekhov seems to share the same position, describing places, circumstances and human experiences as deeply and indissolubly intertwined. His new perspective on the Russian landscape testifies to an ongoing physical and cultural change, and his innovative position in Russian literature clearly deserves a more complete spatial-oriented analysis ${ }^{3}$, alongside more traditional philological approaches. Before developing my observations about the garden as a metaphor for the whole historical period, my reflections need to cross-reference certain tópoi of Russian literature, such as the forest and its semidivine creatures and the complex symbology of the tree, which also undergoes a dramatic shift in Chekhov's works. I shall finish with The cherry orchard, explaining how the difference between sour-cherries and cherries becomes a symbol of Chekhov's poetics and dramatic construction, built on nuances and subtle shifts in meaning and representing the irrevocable fading of a culture.

${ }^{2}$ Barbara Hui is the creator of the Project Litmap, developing digital maps based on literary constructions; the project is a reference for spatial-oriented studies of literature from a practical perspective.

${ }^{3}$ Paying attention to the geospatial shape of the narrative entails a specific observation of more subjective and therefore "slippery" concepts of spatiality at work in the narrative, including different interpretations of space as determined by the global and local perspectives, as well as by the perspectives of colonialism, imperialism and migration, which overwrite geo-cultural identities. 


\section{Land and Woods}

Life as described in Chekhov's works apparently escapes the dichotomy between city and countryside, considered a main tópos of Russian literature (Čechov 1653-1677). While Lev Tolstoy's works described the vastness of the Russian territory or big cities' social life, Chekhov's preferred setting was in the countryside - and especially rural estates - with the perceptible influence of little provincial villages and of the intimate emotional world of their characters. This is the real core of the action, both in his plays and in the majority of his novels, continuously evoking memories and projections, steering the characters outwards in search of a dreamt reality. The perception of nature also relates to this movement: while the centrifugal force of the imagination pushes rural middle class characters outside of their own sphere, their intrinsic inertia keeps condemning them to stillness, and it is the garden that frames this immobility. The garden represents the frustrated search for a wider dimension; here nature takes on a new shape and symbolic value while appearing domesticated and reframed, harmless and deprived of the impulsive strength of other natural manifestations within the Russian literary tradition.

Chekhov's play comes 60 years after some of the literary works that benchmarked the description of the Russian space, radically changing the perspective adopted towards the environment. While Ivan Turgenev's tales or Tolstoy's The Cossacks (Kozaki, 1863) are among the insuperable examples of literary representation, where the Russian landscape appears as a mythic element, or a "space of resonance of the transcending soul" (Parinello 16), with Chekhov this same land appears to be detached from traditional symbolism and is gradually absorbed by the materialistic vision of a greedy emerging middle class. Chekhov frequently recalls the nature of traditionally represented vast open spaces, but the outlook he attributes to his characters is very distant from this sensitivity from a spatial, temporal and cultural perspective. The mythic Russian prostor, the infinite vastness of the Russian landscape, is barely mentioned in Chekhov's literature - he who travelled to Sachalin and beyond to conduct a census of its population, converted the overwhelming expanse of the Russian territory into a more concrete, measurable and describable space. In Chekhov's works, the attitude towards land is often used as an analogy to express the contrast between two specific types of characters - those who see land as a profit-generating asset, and those who approach it with a sense of belonging. Chekhov's production steers towards an antithesis of the characters. Nevertheless, this contrast seems to be intrinsic to the historical moment. The contrast is not just between the two different positions of the engaged individual interacting with the world and the detached, but more self-aware, one. It resides much deeper, establishing a psychological dualism within the same 
characters, pushed by events to question their own place in society. The escalation of this psychological conflict is often used in his plays to promote moral values and to lead the spectator towards a profound reflection on contemporary social changes. With Chekhov, it is generally evident that land is for the first time symbolically lowered to the level of the vulgar pragmatism of the rising middle class, whose aim is to acquire decaying properties from their old aristocratic owners, in a bid to leave behind their past of poverty and servility. This aims to represent the inner contrasts of Russian society and to give voice to its long-silenced members:

The cherry orchard is now mine! Mine! Mine! [...] If only my father and my grandfather could rise from their graves and see all that has come to pass, see their Yermolai, their beaten, barely literate Yermolai who used to run about in winter barefoot, see that same Yermolay buy the estate, the fairest thing on earth. I have bought the estate where my father and grandfather were slaves, where they weren't even allowed into the kitchen (Chekhov 2002a: 330).

Russian land as a wild and mysterious space is already distant and only retains an evanescent connection with the present, lost in the melancholic perspective of a frustrated aristocracy. Perspectives have now drastically changed on both extremes of society's spectrum. Since 1861, thanks to the emancipation operated by Alexander II, former serfs had the opportunity to gain wealth and status, while aristocrats became impoverished and often unable to care for their estates. Chekhov had the opportunity to closely observe the effects of this epochal shift, and The cherry orchard is the play that most strongly voiced the social and economic sentiment of Russia at that time. As stated by Weston:

Chekhov was caught between two opposite forces of Russian economic society - which he was unable to resolve. On the one hand there were dreamers, preservers of beauty, and on the other hand there were those who strived for progress and a better Russia. The two points of view are incompatible and evidently caused Chekhov (a believer in progress and a lover of natural beauty) much consternation (Weston 1279).

Rather than juxtaposing city and nature, Chekhov embraces a poetic of nuances and "in-betweenness", focusing on alternative settings capable of constituting a better frame for the decay of rural aristocracy but also for the search of a productive middle way. Both the liveliness of city life and the natural solemnity of the woods are elegant, and these two places are embodied by specific literary sensitivities and personalities. To these two places Chekhov juxtaposes the estate, a middling dimension hosting mediocre identities, where both environment and society are condensed and domesticated in their nature, as in a crystal ball. The faded villas of the countryside lack elegance: they retained and echoed the frustrations of their inhabitants, who spent their lives looking at their unrealised dreams. These are melancholic characters, without passion, trapped in nets of all-con- 
suming stagnant relationships and in claustrophobic family nucleuses. From this general condition come most of the recurrent purposes of Chekhov's theatre and novels: memories and dreams of travels away from the estate, observing through windows, personifying nature and a whole dynamic of arrivals and departures that are useful to keep the situation absolutely immutable on the inside. All reality is measured through its reflections on the homeostasis of the villa, (e.g. in the text The fiancée (Nevesta, 1903):

The garden was quiet, cool, and shadows lay dark and peaceful on the ground. From somewhere far away, very far, probably outside town, came the calling of frogs. May, sweet May, was in the air! She breathed deeply and wanted to think that, not here, but somewhere under the sky, above the trees, far outside town, in the fields and woods, spring's own life was now unfolding, mysterious, beautiful, rich, and holy, inaccessible to the understanding of weak, sinful human beings. And for some reason she wanted to cry (Chekhov 2020: 288).

Chekhov marks a relevant change in relation to Pushkin's or Tolstoy's works, which can be résuméd as the definitive detachment from both the superhuman dimension and pure wilderness. This increasing distance is represented by the loss of contact with the forest as a sacral symbol. The forest, as represented for example in Oblomov (Goncharov 106-113, 185) or in Rudin (Turgenev 164) is a mysterious place which the sun cannot completely penetrate, a kingdom perpetually in the shadows, often described as a place of metamorphosis inhabited by mythical creatures representing a bridge between nature and divinity. In Chekhov's work, this connection is either lost or just a memory of ancient times. In novels like The black monk (Chernyy monakh) or The steppe (Step') and in plays like Uncle Vanya (Dyadya Vanya) or The cherry orchard, the forest is represented as completely detached from people's lives and differs from previous literary representations. Chekhov still feels the supernatural connotation of this territory, where man's logic loses all power, but this mythical dimension has already been blurred with growing speculation and nature everywhere is progressively weakened by greed. The decadence of this transcendental space becomes a symbol of the loss of faith and morality, conveying the idea of a new generation of individuals for whom profit and self-affirmation represent superior values. As Simon Karlinsky and Michael Heim accurately claim, Chekhov moves away from pure idealism and materialistic superficiality; he is cautious about the enflamed disruptive energy of the new generations but also very critical towards the passive attitude of the middle class (Karlinsky, Heim 69).

As already mentioned, besides not intending to typify in the slightest, Chekhov knows very well that establishing marked distinctions between the characters is an effective dramatic tool, allowing the action to develop and pushing the public towards a more conscious position. The impasse in his plays is therefore expressed by both the opposition of extreme opinions and the intrinsic dualism 
of certain main characters that, nevertheless, represent the real transformative element of Chekhov's theatre. The characters' inner conflicts are often expressed through the observation of others, who point out their incongruences, indirectly giving the author the opportunity to express each figure's concreteness and complexity. This is for instance evident in Uncle Vanya, where the figure of Astrov is presented from quite antithetical perspectives before giving him the chance to clearly express his ideals:

There are fewer and fewer forests... Rivers are drying up, game is becoming extinct, the climate is damaged and every day the earth is becoming poorer and uglier. [To Voynitsky] You're looking at me ironically and think all I'm saying isn't serious, and... And perhaps this really is just craziness, but when I go past the peasants' woods, which I saved from destruction, or when I hear the hum of my young trees, which I planted with my own hands, I know the climate is a little in my control and that if in a thousand years man is happy, the responsibility for that will in a small way be mine (Chekhov 2002a: 154).

His genius is later remarked through the words of Yelena, who takes his love for nature and his vision of the future as proof of his sublime soul:

It is not a question of trees or medicine... You see, my dear, it's talent! And do you know what talent means? Courage, a free mind, a broad sweep... He plants a tree and is already seeing what will follow from it in a thousand years, already he has visions of the happiness of humanity. Such people are rare, to be loved... He drinks, he's often a bit coarse - but what harm in that? A man with talent in Russia can't be nice and clean [...]. (Chekhov 2002a: 171).

Despite his wild and antisocial attitude in the context of the play, Astrov is described as a pure figure, a man of science who cares for nature in all its manifestations. He is the only character resisting the influence of new landowners and of the old degraded middle class. Like Chekhov himself he is a doctor, loves nature, and his main concern is to preserve the woods; we can see in him a possible solution for the dichotomy between homo doctus and homo naturalis, that some critics have considered one of Chekhov's main themes (Barilli 35-36; Ossola 61-68).

\section{Homo faber}

Chekhov undoubtedly searches for a meeting point between these two opposite typologies; in this sense the possibility to reconcile the characteristics of the homo doctus and homo naturalis seems unrealisable without the intervention of another figure: homo faber, a man that embodies action led by moral values and is able to mediate between the natural environment and the service of human necessities. The strongest conflicts among Chekhov's characters revolve around 
these potential homo faber figures, which can emerge from the evolution of both the apparently brightest figures in the plays, such as Astrov in Uncle Vanya, or quite grim ones such as Lopakhin in The cherry orchard, who is motivated by destructive emotions and by the aim to achieve social redemption by any means necessary. Chekhov clearly links these figures with nature but along his production he makes this relationship more symbolic and abstract.

In order to properly understand Astrov in Uncle Vanya, we must go back to The wood demon (Leshiy), an older play based on which Chekhov elaborated this character. Here the protagonist, Khrushchov, is provocatively called Leshiy ${ }^{4}$, which is also the name of the wood demon itself. This character can be considered a prototype of Astrov.

It is known that Chekhov's first plays were attempts at finding a compromise between old theatrical forms and the contents of a newer age (Borny 99), and here the construction of the drama via "indirect action" was not yet mature (Gottlieb 182). Nevertheless, reading his early plays allows us to observe how the author manipulated the original characters in order to make them serve a superior function in his later works. He states: "My goal is to kill two birds with one stone: to paint life in its true aspects, and to show how far this life falls short of the ideal life" (Josephson 150).

In The wood demon Chekhov's attention was initially concentrated exclusively on Khrushchov, and his idealistic vision compared to Astrov's was far more extreme and intolerant. Khrushchov is a wild type - his nickname in fact refers to his attitude, which prevents him from empathising with other people and leads him to follow his own ideals exclusively and obsessively:

KHRUSHCHOV [sic] - Everything is ruined (wrecked), destroyed, everything is falling apart. You call me Leshiy, but not just in me, in all of you lives a wild demon of the woods: you all are wandering around blindly groping in a dark forest. Intelligence, heart and common sense are enough to destroy your and other peoples lives (The wood demon - Chekhov, 1993: 103).

The kind of change that Chekhov operated passing from the first character (Khrushchov) to the second (Astrov) seems to be anticipated in their very names. The first meaning 'beetle', the second meaning 'star'. These details reflect the evolution of the symbolic elements of the plots and the intent to create figures depicting psychological complexity and realistic density. Despite the more subtle definition of his mature characters, the contrasts between homo doctus and homo naturalis still seem present and irreconcilable. Yet, they are sometimes curiously

${ }^{4}$ The adjective leshiy derives from les (woods). The meaning of the adjective is "he who comes from the forest" and may be considered the equivalent of the Latin adjective silvanus, also referring to a tutelary forest deity. In Russian mythology it is an anthropomorphic fabled creature, the soul of the woods (see Ožegov, Švedova 325). 
similar in terms of certain deep beliefs, experiences or feelings - in this case, loving the same woman. The mature character of Astrov is his first attempt to approximate these two conflictual personalities. Using the recurrent theme of the sale of a family property, Chekhov aims to represent the decadence of his time through the irreconcilable conflict between individual interest and super-individual values. This theme is even reinforced in the transition from one play to the other, leading to The cherry orchard, the final step. Therefore, we must recognise that Chekhov's primary interest is always the description and analysis of human life, its reactions and adaptation to the social environment; the personal tie with nature really functions as a social description and must also be read in this sense.

Besides this, we must also consider that the attempt to bring concrete and relatively "trivial" elements of contemporary life on stage dramatically proposes a programmatic vision of Russian theatre (Evdokimova 404-412), dedramatising it and moving away from the romantic aesthetic of astonishment. In his plays Chekhov is never neutral, and while conceiving his plots he is also clearly proposing a representation of his concept of theatre: "[...] contemporary theatre is not above the crowd, but, on the contrary, the life of the crowd is more intelligent and above theatre (Letter to Shtcheglov, 22 February 1898)" (Karlinsky, Heim 328).

Property sale is the common purpose in both Uncle Vanya and The cherry orchard, and we can definitely observe an evolution in relation to this final event and its dramatic function. In his writing process Chekhov changed the attitude towards the symbology of the sale - which actually takes place only in his very last play - and decided to define it more precisely, using it also to raise public awareness regarding inner social divisions and the future of Russia: the sale is in favour of modernity, and nature becomes the victim of human interests. The garden is finally destroyed:

Everyone come and watch Yermolay Lopakhin bringing the axe to the cherry orchard and the trees falling to the ground. We'll build the datchas and our grandchildren and grand-grandchildren will see a new life here... (Chekhov 2002a: 331).

With this sentence Chekhov depicts something that would have been ontologically impossible for previous generations, representing the logical response to previous social injustice. For the same reason the dichotomy between homo naturalis and homo doctus seems too reductive to define Chekhov's vision and leads to the necessity of discovering a middle way between them that will open up the door to the future:

I have no faith in our intelligentsia; it is hypocritical, dishonest, hysterical, ill-bred and lazy. I have no faith in it even when it suffers and complains, for its oppressors come from its own midst. I have faith in individuals, I see salvation in individuals scattered here and there, all over 
Russia, be they intellectuals or peasants, for they're the ones who really matter, though they are few (Letter to Orlov, 22 February 1899) (Karlinsky, Heim 340).

While perishing, the garden shifts its symbolic value from an aesthetic product to a cathartic space.

\section{The tree and the garden}

The forest is, therefore, symbolically vanishing, along with the whole value of transcendence and spirituality; it remains alive for some characters, while it is reduced to a mere spot on a geographic map for others. This, nevertheless, leaves space for another transformation in the landscape: a symbolic renovation of the motive of the tree, in contrast to previous literary examples.

The tree as a symbol of life is an ancient literary tópos, especially as a symbol of human life and social community (Sundqvist, Mitchell 163-190). A dialogue between Yevgeny Bazarov and Anna Sergeevna in Fathers and sons (Ottsy i deti) illustrates this point:

I can tell you it isn't worth the trouble to study separate individuals. All people resemble each other, in soul as well as body; each one of us has a brain, spleen, heart, and lungs, all made similarly. So-called moral qualities are also shared by everyone: small variations don't mean a thing. A single human specimen's sufficient to make judgments about all the rest. People are like trees in a forest; no botanist would study each birch individually (Turgenev 1996: 55).

Human beings are like the trees of a forest, insofar as all together they form a whole. Unlike the forest, however, they do not benefit from a greater unity all together; they are not an entity, they do not exert transcendental power or constitute a community - they merely represent humankind. This differentiates the concept of a forest from the idea of a cluster of trees, and at the same time proposes a reflection on the concept of a symbolic collective identity. While we could find many other interesting examples, I am merely using this quote to highlight a more specific point: the shift in the symbolic interpretation of the tree. In $19^{\text {th }}$ century literature, trees are frequently mentioned though never considered as a whole category. They are classified based on their species, each with a specific symbology. The species most frequently mentioned are birch trees, oaks and acacia. Overall, there is no mention of fruit trees, and this is actually the main difference encountered when we start approaching Chekhov's works.

Chekhov sees the mystic aura of the woods in fruit trees, though condensed in a reduced dimension of nature, perfectly suited to the setting of the villa. In The cherry orchard, the garden is actually a piece of land with an extension almost integrated with the house, a sort of outdoor living room. This orchard is as an 
emanation of mother nature adapted to human proportions and needs. While these trees have an owner, the forest trees are examples of free existence, creatures of the divine, they belong to the land and are part of it.

Chekhov's reflection on trees is at the centre of The cherry orchard, though it had also been developed in previous short stories where the garden revealed a superior function, such as a place of spiritual enlightenment. Fruit trees have a more direct relationship with human beings. Their beauty nourishes the human soul, and their fruits nourish the human body. Unlike the plants of a vegetable garden, they can support their own growth, though they only produce good fruit when treated with care. Thus, the garden is a symbol of human capacity, generosity, intelligence and dedication.

Chekhov specifically develops this concept in two short stories: The black monk and The fiancée. In The black monk, the garden is directly linked to caring for the fruit trees, while the woods are a place associated to madness and loss of clarity. Conversely, in The fiancée - the composition of which is almost contemporary to The cherry orchard - the garden is a symbolic projection of rural aristocracy, which built its richness on the work of the peasants without contributing to the society. In both stories the garden is associated with social and moral decadence, compromising its productivity. In The black monk, the orchard and the woods are directly opposed. The first exposes the elderly landlord's apprehension - the agronomist Yegor Semyonitch - concerned about the garden's fate after his death, while the second, the forest, the place of the encounter with the mysterious black monk, exposes the obscurity of the unconscious and loss of control. Furthermore, the orchard represents the development of practical skills, the use of intelligence, technological advancement and a generous and productive attitude towards the future.

Chekhov's conception of The cherry orchard stemmed from a very precise image. In a conversation with Stanislavsky, he announced that he had in mind a play inspired by the image of a cherry tree branch entering through an open window (Stanislavsky 23). This is the original point from which the author started building the dramatic plot. In the same conversation, Chekhov told Stanislavsky that he had already chosen the title of the play: Vishnëvyy sad. He burst out laughing, surprised that Stanislavsky could not grasp the irony of the expression. After some time, Chekhov decided to clarify the concept with Stanislavsky: "It's not vishnevyy, but Vishnëvyy Sad" (Čehov 1997: 434) once again laughing at the irony. At the time, Stanislavsky did not grasp the subtlety of this differentiation and only later understood the semantic value that Chekhov wished to conjure through the subtle variation between the two adjectives ${ }^{5}$.

5 The difference is determined by the position of the tonic accent that shifts from the first syllable (vish) to the second (vish-në-vyy). Two different forms can ensue from playing with this accent 
At first I did not understand what the discussion was about, but Anton Pavlovitch kept savoring the title of the play, insisting on the sweet sound $\ddot{e}$ inside the word vishnëvyy, trying by mean of it to represent the beauty of the life of the old days, now useless, that he in his play was demolishing through the tears. On that occasion I understood the fineness of that: vishnevyy sad, is a 'business' garden, commercial, that brings profit, while vishnëvyy sad, doesn't bring any profit, it preserves in itself and its pure glowing whiteness the poetry of the old refined life. That garden grows and flourishes as a treat for the spoiled eyes of aesthetes. It is a pity to destroy it but it's necessary, hence this is required by the country's process of economic development (Suhih 409-410).

The term vishnevyy has now almost disappeared from contemporary dictionaries, and has fallen out of use. We could say that it has been assimilated by vishnëvyy, though, at the time the play was created, the author could still discern a very specific difference between the two terms. Chekhov associated vishnevyy to the adjective deriving from cherry - the word vishnya - an adjective suitable to describe products deriving from the confection of the fruit, and therefore immediately reminiscent of the tree ${ }^{6}$ and of the labour necessary to obtain a specific product. For the author, the adjective vishnëvyy retained a romantic nuance, recalling the red colour typical of cherries or sour-cherries as well as a more descriptive connotation, distant from any specific contextualisation ${ }^{7}$. This distinction acquires greater significance when we consider that vishnya is the sour cherry, a fruit particularly appreciated for the artisanal products made from it, typical of certain Russian regions. These elements create a direct link between the image of the garden and the decay stemming from the loss of human productive capacities, while showing the importance of interpreting Chekhovian spaces through a socio-polit-

\footnotetext{
- different not only in meaning but also in their phonic aspect, vishnevyy and vishnëvyy. The $e$, when accentuated and in a velar phonetical context, becomes $\ddot{e}$.

${ }^{6} \mathrm{He}$ stresses the root of the word - the accent being on the radical syllable - to highlight the direct derivation of this adjective from the name of the fruit.

7 The sour cherry tree, vishnya (višnâ) - from which the adjective vishnëvyy (višnëvyj) derives and the play gets its title - is scientifically called Prunus Cerasus, and is a kind of wild cherry tree, not "the" cherry tree - Prunus Avium - whose fruit is red and called chereshnya (čerešnâ). In the dictionary prepared by Vladimir Dal' Tolkovyj slovar'živogo velikorusskogo âzyka under the word vishnya (višnâ) we find vishnëvyy (višnëvyj) as an adjective coming from the sour cherry (Dal' 185). Vishnevyy (Višnevyj) is mentioned as an adjective in one case as associated to kley (klej), gumi, meaning sour cherry resin, sour cherry rubber. In a more recent dictionary Russko-ital'ânskij slovar'the adjective appears only in the form with $\ddot{e}$, under which the two variants were resolved (Majzel', Skvorcova). In a more ancient dictionary, Slovar' russkogo âzyka XVIII veka we finally find two forms vishnevyy (višnevyj) and vishnëvyy (višnëvyj): vishnëvyy (-oj) (višnëvyj (-oj)), vishennyy(-oy), aya, oe (višennyj(-oj), â, oe) and vishniy (yaya, ee) (višnij (ââ, ee)). 1. related to the sour cherry. 2. vishnëvyy (višnëvyj): dark red, colour of the sour cherry (Sorokin 181). The two forms have been registered from various $18^{\text {th }}$ century dictionaries, among them: Leksikon treâzyčnyj, sireč' rečenij slavenskih, ellinogrečeskih i latinskih sokroviŝe (Polikarpov-Orlov 47); Slovar'Akademii Rossijskoj 720-721; Novyj rossijsko-francuzsko-nemeckij slovar' (Gejm 79).
} 
ical perspective ${ }^{8}$. All this is reinforced by the words of the elderly servant, Firs, the only character retaining memories of the old times, back when the garden had a different relevance, both symbolically and economically:

LYUBOV - Cut it down? My dear man, forgive me, you don't understand anything. If there is anything interesting, even remarkable, in the whole of this province, it's just our cherry orchard. LOPAKHIN - The only thing remarkable about the orchard is that it's very big. The trees bear fruit every other year, and you can't do anything with the fruit, no one buys it.

$[\ldots]$

FIRS - In the old days, forty or fifty years ago, they dried the cherries, soaked them, marinated them, made jam, and they used to...

GAEV - Be quiet, Firs.

FIRS - And they used to send the preserved cherries, whole wagonloads of them, to Moscow and Kharkov.... That brought in money! And the dried cherries, then were soft, juicy, sweet, perfumed... They knew a recipe then...

LYUBOV - And where's that recipe now?

FIRS - They forgot it. No one can remember it (Chekhov 2002a: 292-293).

This resumes a contest of abandon and the lack of a resolutive figure; far from the value of work and dedication, these fruits can only be observed in their beautiful sterility. The estate is already detached from any intrinsic value and needs to be reabsorbed into a new reality, reconfigured in order to find a new purpose.

\section{Vill'Amarena: A sour cherry orchard}

I am here borrowing from the Italian poet Guido Gozzano's "sour cherry villa", curiously Chekhov's coeval and representing the same decadent spirit. In the beautiful poem La signorina Felicita, the element of the sour cherry garden comes back with the idea of an old-fashioned society that needs to give way to a modern age, forecasting a social and environmental reconfiguration. Chekhov's play makes no real distinction between the garden and the house - both are the part of a private familiar space, a microcosm representing a vanishing way of life. In this sense we can say that the core of Chekhov's perspective is not the dichotomy between the countryside and the city, but the abandonment, the imminence of change, the fear of a transition implying unknown coordinates. All the characters of The cherry orchard - apart from Lopakhin - refer to the garden with a certain

\footnotetext{
${ }^{8}$ Abandoning definitively any Cartesian concept of space, Henri Lefebvre defends a concept of space that is irreducible to a "form" imposed upon physical materiality and that is fundamentally produced by and through human actions (Lefebvre 26-27). The idea of space as a product continuously shaped and transformed by social agents in relation to their particular economic, cultural, and political structures has also been developed by Edward Soja in his Thirdspace: Journeys to Los Angeles and other real-and-imagined places, Oxford, Blackwell, 1996.
} 
nostalgia for the old times. The characters have left their own identities in the past and are not able to recreate them; substantially diminished, they live crystallised in a timeless and meaningless present, fearing the future. Dismantling the estate means renouncing the social identity that had always absorbed them completely. The end of the garden suggests a cathartic epilogue for these characters, opening up new possible solutions for their lives.

The estate in itself is an icon of this era: both the inside and the outside of the master's house can be considered a portion of the private space defining the identity of the familiar unit. The estate is the epicentre of the countryside lifestyle of the decadent and melancholic fin de siècle, the only place that can be opposed to the rise of the city as a mythic place of modernity. This in itself is tied to another fundamental symbol of modernity: the railroad. The railroad physically connects different spaces with well distinguished values and attitudes, and clearly brings a new idea of time constantly connected to the idea of a fast approaching future, but also enhances the existence of different times and life rhythms which coexist on the same Russian territory (Jackson 130-151). The villa can clearly be seen as an extension of the $19^{\text {th }}$ century's aristocratic main halls, the predominant venues for social encounters and role negotiation: contrary to the salon des fêtes, the estate is permeable, its structure is less rigid and it perfectly represents the transition into a more eclectic society with multiple needs, dreams and frustrations. In Chekhov's work, this element is highlighted by the range of linguistic registers as well as by the diversified gestural depictions - aristocracy, peasants and new landowners are vividly portrayed - and by the director's notes (Stanislavsky 206-354), indulging in connotations brushing against stereotypes to recall specific human typologies. Even so, we perceive in all these figures a sense of transition, as well as the fact that they are all involved in a process aiming to define their own identities.

The villa - its spatial continuity linking the inside to the outside - is in itself a porous space, open to a continuous architectural and social reconfiguration and perfect for framing the upcoming rapprochement of the classes. This becomes evident in Chekhov's director's notes, that need to be taken not as a paratext but as a primary element of scenic writing, providing many descriptive elements filling up the scene as eloquently as the interpreted words. To this extent, the sketches for mises en scène created by Stanislavsky also provide significant help, produced as they are under the author's constant supervision and amendments, providing the appropriate interpretation of the scenes. The director's drawings and the pictures created from the play's first performances testify to an explicit intention to break away from any kind of classical spatial definition (Fig. 2-3).

Stanislavsky's scenic design clearly reflects this transversal approach to space. The different areas of the estate are not represented frontally and statically, but diagonally cut at the level of the proscenium, providing continuity to the action and 
compensating the dramaturgical stillness of the four acts. This perspective enhances the realism of the domestic space's representation, linking the intimate life of the characters to the natural life outside of the house. This perspective guarantees greater significance to the movements upon the stage against the resistance of the characters' psychologies, whilst balancing the effect of the prolonged pauses between sentences. Chekhov's theatre is notoriously linguistically dry and rich in meaningful silences, although we need to remember that his plays include many indirect actions, sounds and noises both on and off stage, and that these elements bring the scene closer to the senses of the public. This spatial continuity fosters the public's perception of the setting and allows to register all acoustic information as a whole musical score, without any sharp distinctions between inner and outer elements. The intent to create a fluid and perceptive space between the scene and the audience produces a direct impact on the public's emotional involvement, exposing the spectators to a continuous dramatic space where the characters' emotions can meet their own projections.

The continuity between house and garden becomes significant in the play's finale, where the garden is demolished to make space for modernity, also eradicating symbolically a whole way of living. Once again, another interesting element emerges from Stanislavsky's drafts: Chekhov had in mind a precise organisation for the garden - described at the very beginning of the second act (Chekhov 2002a: 303 ) - with the presence of gravestones on stage, an element leading us to a different interpretation of some of the scenes, like this one between Anya and Trofimov:

ANYA - What have you done with me Petya, why don't I love the cherry orchard as I used to? I loved it so dearly, I thought there was no better place on earth than our orchard.

TROFIMOV - All Russia is our orchard. The land is great and beautiful, there are many beautiful places in it. [a pause] Just think, Anya, your grandfather, your great-grandfather and all your ancestors were serf-owners who owned living souls and those human beings must surely be looking at you from every cherry-tree in the orchard, from every leaf, from every trunk, don't you hear their voices?... (Chekhov 2002a: 316).

The dialogue suggests a link between the trees and the tombs, establishing between them a painful cause and effect relationship. These were also clearly represented in Stanislavsky's drawings (Fig. 1), approved by Chekhov himself. In the director's mind, the tombs' and the chapel's presence would contribute to a more diachronic vision of the place, enriching the spatial transversality of the scene with a new parameter, bringing the small familiar dimension of the play to a broader scale. In other words, this interpretation of the setting offered a visual representation of the evocative elements used by Chekhov in his dramatic construction. The scene just quoted above is built on the metaphoric transformation of the white flowers into open eyes, staring at the house from the outside and calling for the attention of the inhabitants. 
Trees are also personified in the first act of the play, when Ranevskaya sees the image of her mother - who had died some years before - wandering around the garden dressed in white. Both these moments of the play reveal a curious exchange of glances between the inside and outside of the house as well as between past and present, all these dimensions being tied together by the pure intensity of the white colour. In fact, the white colour dominates the play: from the early morning hoarfrost to the mother's dress in Ranevskaya's vision and to the whiteness of the cherry trees, in bloom at the beginning of the play and bare at the end ${ }^{9}$. Chekhov's precise descriptions of plant species and of their transformation throughout the seasons must be considered in relation to both the literary tradition and his very personal experience in floriculture. For Chekhov, nature is an everyday experience and a passion, as revealed in his letters, where he often mentions cultivations, prunings and cuttings (Karlinsky, Heim 7, 20, 50, 222, 290, 370). In the author's letters, his life appears to be a continuous search for the ideal place, a house with a garden where he plans to settle with the family (Gillès 463$)^{10}$. He sweetly reminisces about details of countryside life such as liqueurs and homemade preserves. Sour cherries are mentioned as a significant childhood memory, a sort of Proustian madeleine bearing the value of a symbol shared by a whole Russian generation.

The letters allow us to better understand the literary works and the serene character of the author, lucidly and positively looking at the present and at the future. Chekhov observes people with scientific attention, delicate manners and compassion. In the following dialogue, extracted from the novel The black monk, the agronomist Yegor Semyonitch expresses a specific feeling for his orchard, reminiscent of Chekhov's sentiments and of the cherry orchard's situation:

I'd like to know, what will happen to the garden when I die? It won't be kept up to its present standard for more than one month. The secret of my success isn't that it's a big garden, with lots of gardeners, but because I love the work - do you follow? - perhaps I love it better than myself. Look at me: I work from dawn till dusk. The grafting, pruning, planting - I do them all myself. When people start helping me, I get jealous and irritated until I'm downright rude to them. The whole secret is love, and by that I mean the keen eye and head of the master looking after his own place, the feeling that comes over you when you've gone visiting for an hour and you just sit still. But your heart is not there, you're miles away - afraid something might be going wrong

9 The first act of the play is set in May and Chekhov draws attention to the blossoms on the trees. The sale of the property occurs on the $22^{\text {nd }}$ of August and takes place at the beginning of the third act. The fourth act is set at the beginning of September as Anya is about to leave to attend high school. The second act is a typical summer scene and is all set outdoors. This also allows to make a distinction between the present and the memories of the past, where the garden is always in bloom, in a sort of mythical and immutable temporality.

10 This theme is dominant since his childhood, when the family had been obliged to leave the Taganrog property and move to Moscow. Chekhov bought various properties trying to find another location to settle the family "nest" again. He never abandoned this project, though as he grew older he had to accept a more stable lifestyle. 
in the garden. [...] the principal enemy in our work isn't hares, cockchafers, or frost, but the man who doesn't care (The black monk - Chekhov 2002b: 121-122).

Chekhov deeply feels the gradual loss of the emotional tie between man and nature, the distance provoked by the growing disaffection between man and land. This lack of love is the end of a sublime natural sodality.

The garden represents the values of a society without herds, which will lose its way because it is incapable of giving value to its historical path, and which will delegate its responsibilities and duties to the new generation of enriched landowners - who are not emotionally attached to the land. Chekhov's attitude, nevertheless, should not be misinterpreted. He implicitly trusts modernity, progress and scientific development, and deeply trusts human potential. The negative aspects of the present do not discourage him but rather steer him towards a more active life and a stronger social engagement (Anton Chekhov, Letter to Orlov, 22 February 1899), (Karlinsky, Heim 258-259). For Chekhov, the richest garden is Russian humanity itself, which he represents in all its surprising, fragile beauty.

The same decadent reality and the same disenchanted outlook can also be observed in the poetry of the Italian Guido Gozzano, telling us that this sentiment transcends the borders of the Russian world and describes the arrival of a whole new era, in which old paradigms cannot fit ${ }^{11}$. In this historical moment, the garden becomes the symbol that embraces the mysticism of the old natural vastness and the frustrated ferity of emerging materialism.

This glance, initiating from the countryside and travelling towards the rise of modernity, is laden with nostalgia - mostly for a future that will remain purely within the confines of the imagination.

TROFIMOV: I have a premonition of happiness, Anya. I can already see it ...

ANYA: The moon is rising.

TROFIMOV: Yes, the moon is rising. [pause]. There it is, happiness, - there it comes, nearer and nearer, I can already hear its steps. And if we don't see it, don't recognise it, it's not so terrible. Others will see it! (Chekhov 2002a: 316-17)

E non sono triste. Ma sono stupito se guardo il giardino...

Stupito di che? Non mi sono sentito mai tanto bambino...

(Guido Gozzano, L’assenza; Gozzano 86)

11 The cherry orchard was performed for the first time on 17 January 1904, while the poem $L a$ Signorina Felicita was first published in "La Nuova Antologia" in 1909. The mentioned association of the two works does not suggest any direct link between them or between the authors, even though it seems plausible that Guido Gozzano knew about a coeval Russian production. Referring to this association, I simply aim to establish a connection between their poetics and suggest the international relevance of this literary tópos with its relative purposes. 


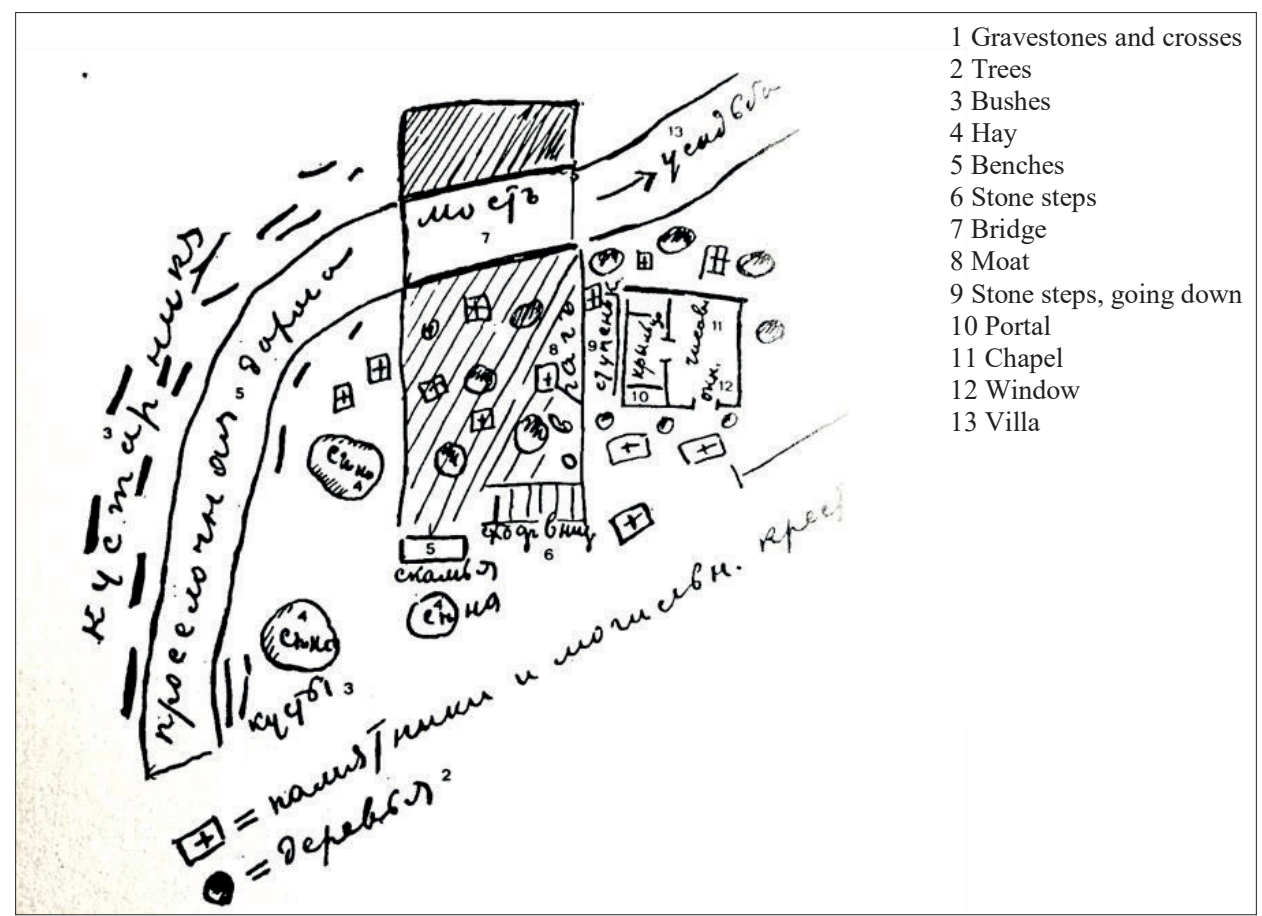

Figure 1. Konstantin Stanislavsky, Plan of the setting for the second act of The cherry orchard (Stanislavsky 246).

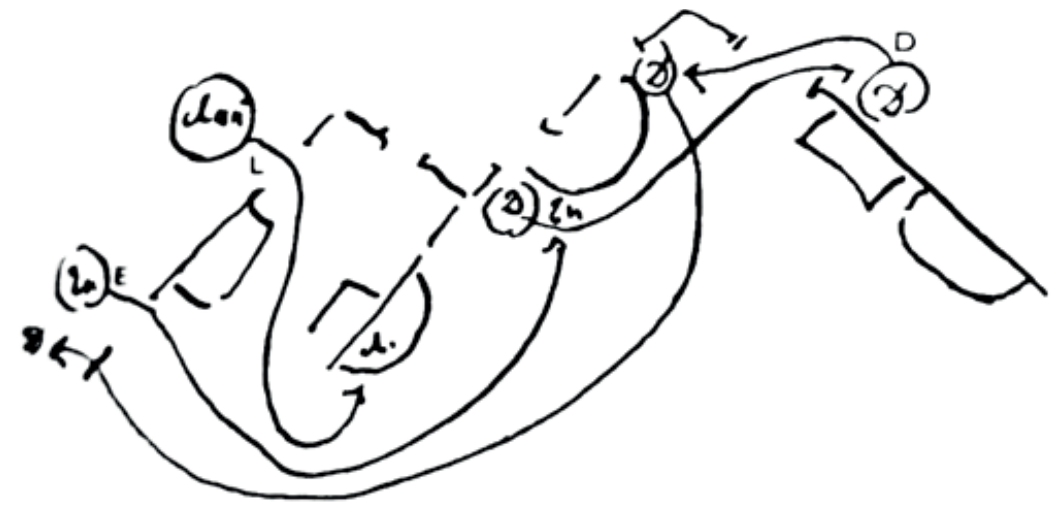

Figure 2. Konstantin Stanislavsky, Plan of the setting for the first act of The cherry orchard (Stanislavsky 207). 


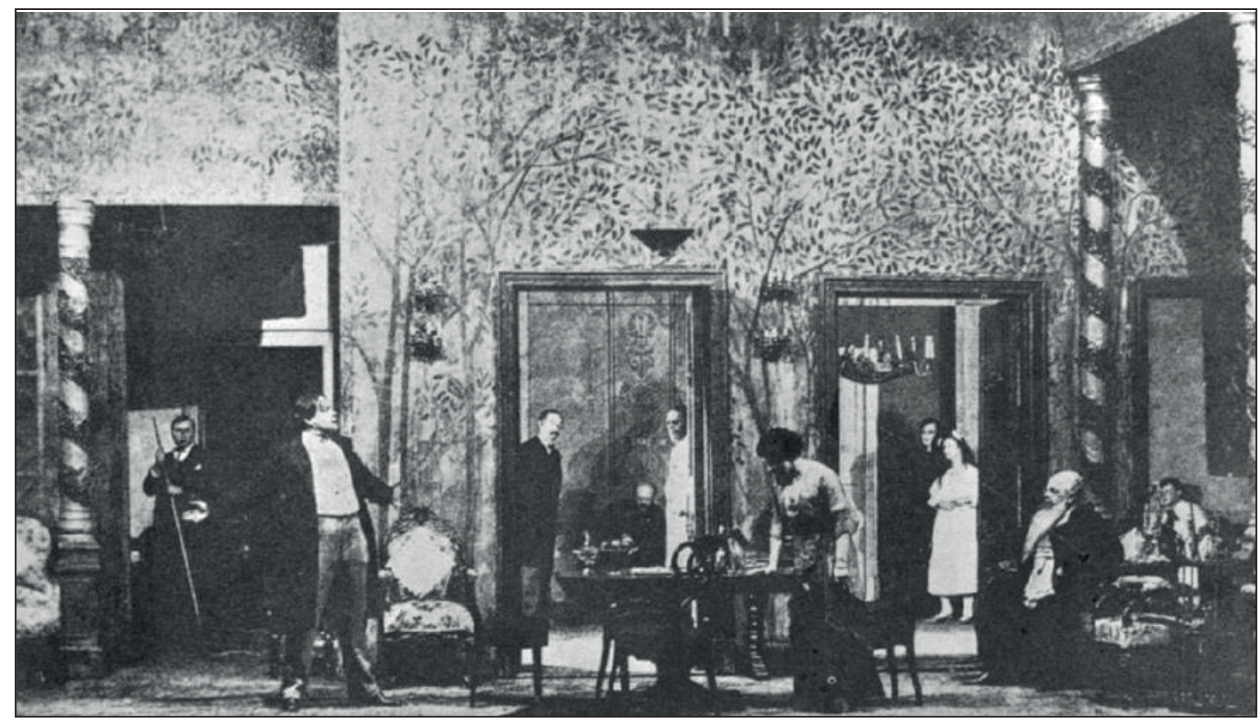

Figure 3. The cherry orchard, Moscow Art Theatre, 1904. The continuity of the spaces is revealed by the stage picture, where the classical V-shape distribution of the actors on scene is broken, all planes are covered and the scene is built asymmetrically (McNamara 80).

\section{Bibliography}

Barilli, Renato. La narrativa europea in età contemporanea. Cechov, Joyce, Proust, Woolf, Musil. Milano, Mursia, 2014.

Borny, Geoffrey. Interpreting Chekhov. Canberra, ANU Press, 2006.

Chekhov, Anton. Fifty-two stories. Transl. by Richard Pevear, Larissa Volokhonsky. New York, Knopf, 2020.

Chekhov, Anton. Plays. Transl. by Peter Carson. London, Penguin, 2002a.

Chekhov, Anton. The wood demon. Transl. by Nicholas Saunders and Frank Dwyer. Newbury, A Smith and Kraus Book, 1993.

Chekhov, Anton. Ward No. 6 and other Stories, 1892-1895. Transl. by Ronald Wilks. London, Penguin, 2002b.

Čechov, Anton. Racconti. Transl. by Bruno Osimo. Milano, Mandatori, 2002.

Čehov, Anton. P'esy, Moskva, Meždunarodnyj izdatel'skij dom, 1997.

Čehov, Anton. Sobranie sočinenij v dvenadcati tomah. Moskva, Gosudarstvennoe izdatel'stvo hudožestvennoj literatury, 1944-1951.

Dal', Vladimir. Tolkovyj slovar'živogo velikorusskogo âzyka. T. 1. Moskva, Tipografiâ F. Semena, 1863.

De Certeau, Michel. "Spatial Practices". The practice of everyday life. Transl. by Steven Rendall, Berkeley. University of California Press, 2002, p. 91-115.

Ermilov, Vladimir. A.P. Chekhov: 1860-1904. Moscow, Foreign languages Publishing House, 1954. Evdokimova, Svetlana. "Unmelodramatizing drama: Čechov's Experiment”. Anton P. Čechov - der Dramatiker. München, Verlag Otto Sagner, 2012, p. 404-412. 
Florenskij, Pavel A. Lo spazio e il tempo nell'arte. Transl. by Nicoletta Misler. Milano, Adelphi, 1993.

Foucault, Michel. "Des Espace Autres. Conférence au Cercle d'études architecturales, Mars 1967". Architecture/Mouvement/Continuité, Oct. 1984, p. 46-49.

Gejm, Ivan. Novyj rossijsko-francuzsko-nemeckij slovar'. T. 1. Moskva, Universitetskaâ tipografiâ, 1799.

Gillès, Daniel. Cechov ou le spectateu désenchanté. Paris, Julliard, 1967.

Goncharov, Ivan Aleksandrovich. Oblomov. Transl. by C.J. Hogarth. New York, Macmillan, 2006.

Gottlieb, Vera. Chekhov and the vaudeville. New York-Cambridge-London, Cambridge University Press, 1982.

Gozzano, Guido. Poesie e prose. Milano, Feltrinelli, 1995.

Jackson, Robert Louis. Close encounters: Essays on Russian literature. Brookline, Academic Studies Press, 2018.

Josephson, Matthew, ed. The personal papers of Anton Chekhov. New York, Lear, 1948.

Karlinsky, Simon, Michael Heim. Anton Chekhov's life and thought: selected letters and commentary, Berkeley, University of California Press, 1975.

Laffitte, Sophie. Tchekhov par lui-même. Paris, Éditions du Seuil, 1955.

Lefebvre, Henri. The production of space, Transl. by Donald Nicolson-Smith. London, Blackwell, 1991.

Lo Gatto, Ettore. La letteratura russa moderna. Milano, Sansoni, 1968.

Magarshack, David. Chekhov the dramatist. London, Eyre Methuen, 1980.

Majzel', Boris, Nadežda Skvorcova. Russko-ital'ânskij slovar'. Moskva, Russkij âzyk, 1977.

McNamara, Brook. "Scene Design: 1876-1965. Ibsen, Chekhov, Strindberg”. The Drama Review: TDR. Naturalism revisited, 13, 2, 1968, p. 77-91.

Moran, Dermot. Introduction to phenomenology. Routledge, London, 2000.

Ossola, Carlo. En pure perte. Le renoncement et le gratuit. Paris, Payot-Rivages, 2011.

Ožegov, Sergej, Natal'â Švedova. Slovar' russkogo âzyka. Moskva, Azbukovnik, 1992.

Parrinello, Giuli L. Il bosco nella cultura europea tra realtà e immaginario. Roma, Bulzoni, 2002.

Piretto, Gian Piero. "Strade ferrate, ville e giardini. Anton Čechov e la cultura dell' «usad'ba»". Dalla forma allo spirito. Scritti in onore di Nina Kauchtschischwili. Milano, Guerini, 1989, p. $169-180$.

Polikarpov-Orlov, Fedor. Leksikon treâzyčnyj, sireč rečenij slavenskih, ellinogrečeskih i latinskih sokrovise. Moskva, Sinodal'naâ tipografiâ, 1704.

Rayfield, Donald. Chekhov: the evolution of his art. London, Paul Elek, 1975.

Ripellino, Angelo Maria. Il trucco e l'anima. Torino, Einaudi, 1965.

Saunders, Corinne J. The forest of medieval romance: Avernus, Broceliande, Arden. Cambridge, D.S. Brewer, 1993.

Slovar'Akademii Rossijskoj. Sankt-Peterburg, Imperatorskaâ Akademiâ Nauk, 1789.

Soja, Edward. Thirdspace: Journeys to Los Angeles and other real-and-imagined places. Oxford, Blackwell, 1996.

Sorokin, Urij, red. Slovar' russkogo âzyka XVIII veka. Vyp. 3. Leningrad, Nauka, 1987.

Spiegelberg, Herbert H. The phenomenological movement: a historical introduction. Berlin, Springer, 1982.

Stanislavsky, Konstantin. Le mie regie, a c. di Fausto Malcovati: Il giardino dei ciliegi. Transl. by Fausto Malcovati. Milano, Ubulibri, 1986.

Strada, Vittorio. EuroRussia, Letteratura e cultura da Pietro il Grande alla rivoluzione. Roma-Bari, Laterza, 2005. 
Strada, Vittorio. Le veglie della ragione: miti e figure della letteratura russa da Dostoevskij a Pasternak. Torino, Einaudi, 1986.

Suhih, Igor. Problemy poètiki A.P. Čehova. Leningrad, Izd-vo Leningradskogo universiteta, 1987.

Sundqvist, Olof, Stephen Mitchell. "The temple, the tree, and the well". Old Norse mythology comparative perspectives. Cambridge, Harvard University Press, p. 163-190.

Thacker, Andrew, Peter Brooker. Geographies of modernism. New York, Routledge, 2005.

Turgenev, Ivan. Fathers and sons. Transl. by Michael R. Katz. New York, W.W. Norton, 1996.

Turgenev, Ivan. Rudin, a novel. Transl. by Constance Garnett. London, William Heinemann, 1900.

Turgenev, Ivan. Sobranie sočinenij v šesti tomach. Moskva, Izdatel'stvo “Pravda”, 1968.

Warf, Barney, Santa Arias. The spatial turn: interdisciplinary perspectives. New York, Routledge, 2009.

Weston, John. "Uncle Vanya: Chekhov's vision of human dignity”. The English Journal, 56 (9), 1967, p. 1276-1279. 